\title{
Removing cyanide by mixed culture at liquid media with variation in $\mathrm{pH}$ and cyanide concentration
}

\author{
Corry Valentina ${ }^{1}$, Rositayanti Hadisoebroto $^{1 *}$, and Astri Rinanti ${ }^{1}$ \\ ${ }^{1}$ Universitas Trisakti, Environmental Engineering Departement, Faculty of Landscape Architecture and Environmrntal Technology, \\ Jakarta, Indonesia
}

\begin{abstract}
This preliminary study aims to investigate removal efficiency of cyanide by mixed culture Thiobacillus sp. and Clostridium sp. in a liquid media stone mineral salt solution (SMSs) with controlled condition. This research variation were $\mathrm{pH} 5,7$, and 9 and cyanide concentrate (ppm) 100, 300, and 500 within erlenmeyer $300 \mathrm{ml}$, for 48 hours at $30^{\circ} \mathrm{C}$. In this research, cyanide artificial $(\mathrm{KCN})$ was presented in liquid media. Analysis of cyanide concentration on liquid medium was done by Gas Chromatography Mass Spectrometer (GC-MS) method. From the research, it was found that the cyanide removal was 50\%, $55 \%, 53 \%$ for cyanide $\mathrm{pH}$ variation $5,7,9$, respectively. In $\mathrm{pH} 7$ was obtained a cyanide removal result of $55 \%$ and while for concentration (ppm) 100, 300, 500 each resulted in allowance of $45 \%, 57 \% 60 \%$. The higher removal $60 \%$ is established at concentration of $500 \mathrm{ppm}$ and $\mathrm{pH} 7$. It could be concluded that mixed culture Thiobacillus sp. and Clostridium sp. could be an alternative to remove cyanide from contaminated water until concentration of $500 \mathrm{ppm}$ with removal percentage of $60 \%$.
\end{abstract}

\section{Introduction}

Environment defilement by cyanide compounds causing damage to our ecosystem. Source of cyanide compounds came from industrial activity, such as mining mineral, arsenic, lead, mercury, cadmium, chromium and sulfuric acid to extracting noble metal like gold ore and silver [1]. Gold ore as a result containing sulphides and cyanide in a large quantities, so the volume of cyanide waste water that generated by jewelry industry usually contain high metal concentration. Cyanide was totally toxic and dangerous for organism and environment [2]. Cyanide can have a negative impact to human's health and animal that causing death, also environment pollution. This toxic liquid residue must be minimalize to reduce the impact [3].

A cyanide is a chemical compound that contains the group $\mathrm{C} \equiv \mathrm{N}$. This group, consists of a carbon atom triplebonded to a nitrogen atom. Cyanide is divided into three groups ; free cyanide associated with cyanide ion $\mathrm{CN}^{-}$ (produced by dissolving sodium or potassium cyanide in water) and hydrogen cyanide gas $(\mathrm{HCN})$; cyanide ions and some metals such as $\mathrm{Zn}, \mathrm{Ni}, \mathrm{Ag}, \mathrm{Cd}, \mathrm{Hg}$; cyanide ions and $\mathrm{Fe}$ [4]. Cyanide removal can be done by adsorption process. The adsorption process takes place chemically using several adsorbents such as silica, manic alginates, activated carbon, polymeric materials. However, the adsorption process using Granular Activated Carbon (GAC) can damage the environment, highly cost and causing demage as a result from secondary pollution [5]. Bioremediation becomes one of the alternative methods to remove cyanide by utilizing the ability of microorganism or plants to convert the toxicated cyanide compounds into simple compounds $[2$, $6,7]$. Cyanide is converted into a source of carbon and nitrogen by various enzymes which exist in microorganisms [8].

Bioremediation has several benefits that are able to eliminate cyanide compounds, have low operating costs, producing high quality materials, and eco-friendly processes [9]. Several types of bacteria that can exclude cyanides such as, i.e. Klebsiella oxytoca can remove $26 \%$, Bacillus sp. can remove $65.5 \%$ [7], Pseudomonas pseudoalcaligenes can remove $99.9 \%$ [6], Rhodococcus rhodochrous can remove $47.78 \%$ [10], Bacillus nealsonii can remove $85.83 \%$ [11], Thiobacillus thioparus can remove $93 \%$ [12].

There are several factor of environmental conditions that affect the performance of microorganisms to remove cyanide, including cyanide concentrations, $\mathrm{pH}$, temperature, nutrients, contact time between cyanides and microorganisms, and the presence of additional pollutants [13]. In some previous studies, researchers removed cyanide by using different bacteria with different conditions. Most of the bacteria that used was include in the class of mesophyll bacteria, whereas the bacteria can optimally grow in $\mathrm{pH}$ range 5,5-8,0. Cyanide concentration on cyanide removal depending on the type of bacteria that used, i.e. bacteria Klebsiella oxytoca at concentration of cyanide $157 \mathrm{ppm}$ can remove $26 \%$, Rhodococcus rhodochrous at a concentration of $150 \mathrm{ppm}$ cyanide can remove $47.78 \%$ [10], Bacillus nealsonii at $100 \mathrm{ppm}$ cyanide concentration can remove

\footnotetext{
Corresponding author: rositayanti@trisakti.ac.id
} 
85.83\% [11] Thiobacillus thioparus at concentration of 50 ppm cyanide remove $93 \%$ [12].

This research is a laboratory scale study with the objective of determining the optimum cyanide removal efficiency. The research uses mixed culture in Thiobacillus sp. and Clostridium sp. on liquid media SMSs with variation in $\mathrm{pH}$ and cyanide concentration.

\section{Research methodology}

\subsection{Bacteria cultivation}

Cyanide (KCN-) is used as an artificial contaminant which is subsequently put into bacteria (Thiobacillus sp. and Clostridium sp.). Medium of bacterial growth using Stone Mineral Salt Solution (SMSs). Batch cultures contained $80 \%(\mathrm{v} / \mathrm{v})$ of SMSs, $10 \%(\mathrm{v} / \mathrm{v})$ cyanide, and $10 \% \quad(\mathrm{v} / \mathrm{v})$ respectively of Thiobacillus sp. and Clostridium sp.

\subsection{Bacteria growth}

Population growth of Thiobacillus sp. and Clostridium sp. in mixed culture is done by using Total Plate Count (TPC) method on petri dish containing Nutrient Agar (NA).

Number of colonies per $\mathrm{ml}$ or per gram

$=\{$ number of colonies per cup $\mathrm{x}(1 /$ dilution factor $)\}$

\subsection{Analysis of cyanide removal}

The cyanide removal will be analyzed using Gas Chromatography - Mass Spectrometer (GC - MS) method. The environmental conditions to remove cyanide in a batch culture are adjusted to a temperature of $30^{\circ} \mathrm{C}$, and contact time in 48 hours. The variations of

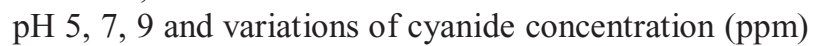
100, 300, 500 is shown in Fig. 1.

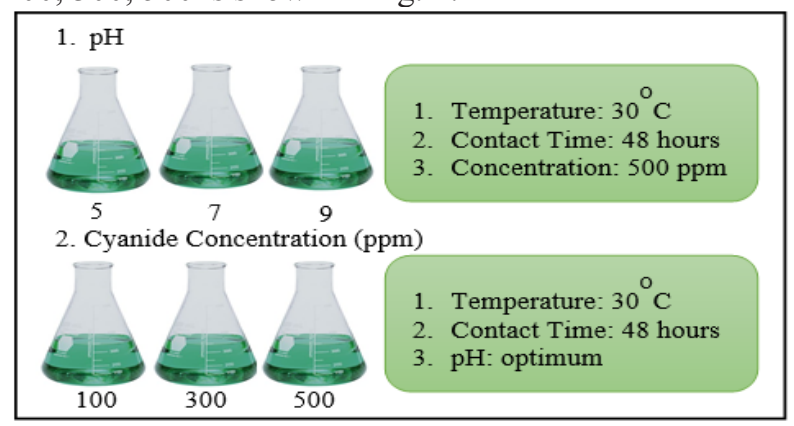

Fig. 1. Cyanide discharge test on liquid media (SMSs).

Variation of $\mathrm{pH}$ used in this research are 5, 7, and 9. Cyanide level will be counted using Formula 1 for each $\mathrm{pH}$ variation.

Formula 1:

$$
R=\frac{\frac{A u}{A b} \times \frac{V b}{V u} \times V e}{W u}
$$

*R: Cyanide Level (ppm), Au: Chromatogram area of the sample, $\mathrm{Ab}$ : Standard Chromatogram area, $\mathrm{Cb}$ : Standard Concentration (ng/ $\mu \mathrm{l}), \mathrm{Vb}$ : Volume of injected standard solution $(\mu \mathrm{l}), \mathrm{Vu}$ : Volume of injected sample solution $(\mu \mathrm{l})$, Ve: Final volume of the sample extract $(\mu \mathrm{l})$, Wu: Sample weight $(\mathrm{g})$.

\section{Result and discussion}

\subsection{Bacterial growth on cyanide}

Thiobacillus sp. and Clostridium sp. can growth on a medium containing cyanide with a concentration of 100 ppm, 300 ppm, 500 ppm can be seen in Figure 2.

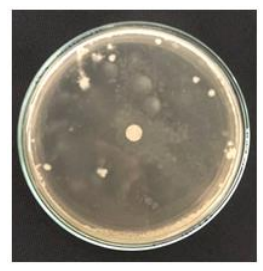

$100 \mathrm{ppm}$

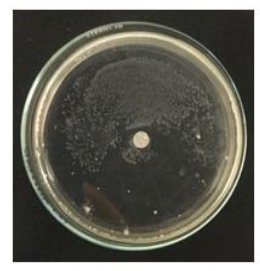

$300 \mathrm{ppm}$

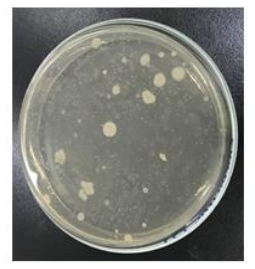

500 ppm
Fig. 2. Test of bacterial growth on a medium containing 100 ppm, 300 ppm, 500 ppm cyanide within 48 hours.

In Fig. 2, it is shown that there is inhibition zone within 48 hours. This can be happened due to the condition of bacteria that can grow on toxic compounds. Thus the bacteria are suspected to be able to remove the cyanide pollutant compound. As described [14] that the diameters formed in the inhibition zone may be an indication of bacterial susceptibility to antibacterial agents. The inhibitory power of bacterial growth can be seen in the area around the paper discs that overgrown by bacteria. If inhibition zone formed around the paper discs that spilled before with various concentrations of cyanide, it indicates that the bacteria are resistant to cyanide. Conversely, if inhibition zone is seen around the paper discs, so the bacteria are sensitive to cyanide.

\subsection{Cyanide removal based on $\mathrm{pH}$ variation}

Data of cyanide removal can be seen from the result of GC-MS temporary test that shown in Table 1.

Table 1. Percentage of Cyanide Levels Removal at Variation of $\mathrm{pH}$.

\begin{tabular}{|c|c|c|c|c|}
\hline \multirow{2}{*}{$\mathbf{p H}$} & \multicolumn{4}{|c|}{ Cyanide Removal (\%) } \\
\cline { 2 - 5 } & $\mathbf{X}_{\mathbf{1}}$ & $\mathbf{X}_{\mathbf{2}}$ & $\mathbf{X}_{\mathbf{3}}$ & $\mathbf{X}_{\text {Average }}$ \\
\hline 5 & 55 & 45 & 50 & 50 \\
\hline 7 & 40 & 65 & 60 & $\mathbf{5 5}$ \\
\hline 9 & 52 & 63 & 44 & 53 \\
\hline
\end{tabular}

In table 1 , the highest removal $(55 \%)$ is occurs when temperature $30^{\circ} \mathrm{C}$, with $\mathrm{pH}$ conditions of 7 for 48 hours. The optimum $\mathrm{pH}$ range for the growth of several bacteria such as Clostridium lies between 6.5-7.5; Klebsiella oxytoca is 7 obtained a cyanide removal $70 \%$ and [10] 
Rhodococcus rhodochrous bacteria is optimum at $\mathrm{pH} 7$ obtained a cyanide removal $47,78 \%$. Table 1 also showed that the bacteria Thiobacillus sp. and Clostridium sp. could live in large $\mathrm{pH}$ range nevertheless optimum bacterial cultivation conditions in the environment, will result in greater of removal.

\subsection{Cyanide removal based on cyanide concentration variation}

With the optimum $\mathrm{pH}$ condition ( $\mathrm{pH} 7)$, then proceed the cyanide concentration variations.

Table 2. Percentage of cyanide levels removal at variation of cyanide concentration.

\begin{tabular}{|c|c|c|c|c|}
\hline \multirow{2}{*}{$\begin{array}{c}\text { Conventration } \\
\text { (ppm) }\end{array}$} & \multicolumn{4}{|c|}{ Cyanide Removal (\%) } \\
\cline { 2 - 5 } & $\mathbf{X}_{\mathbf{1}}$ & $\mathbf{X}_{\mathbf{2}}$ & $\mathbf{X}_{\mathbf{3}}$ & $\mathbf{X}_{\text {Average }}$ \\
\hline 100 & 40 & 45 & 50 & 45 \\
\hline 300 & 61 & 48 & 62 & 57 \\
\hline 500 & 65 & 45 & 70 & $\mathbf{6 0}$ \\
\hline
\end{tabular}

In Table 2, the percentage remove of cyanide removal of $60 \%$ was achieved at a concentration of 500 ppm. This is in accordance with the assertion [15] in previous studies which stated that a mixed culture capable of degrading cyanide by about $57 \%-76 \%$. [7] also said that the mixed cultures of Basillus safensis, Basillus lichenformis, Bacillus tequilensis, and Agrowaste were able to degrade cyanide around 59.75\% $-89.5 \%$ whit concentration $100 \mathrm{ppm}$, and Pseudomonas pseudoalcaligenes bacteria capable of degrading cyanide by $99.9 \%$ [6]. Yet, to reach greater removal the optimum bacterial cultivation conditions in environment should be maintained.

\section{Conclusions}

Mixed of bacteria Thiobacillus sp. and Clostridium sp. can remove cyanide level, it is proved by Gas Chromatography - Mass Spectrometer (GC - MS) in $\mathrm{pH}$ conditions of 7 and cyanide consentrations of $500 \mathrm{ppm}$, resulting $60 \%$ removal percentage.

\section{References}

1. Gould DW, King M, Mohapatra BR, Cameron RA, Kapoor A, Koren DW. A critical review on destruction of thiocyanate in mining effluents. Miner Eng, 34:38-47 (2012)

2. Wu CF, Xu XM, Zhu Q, Deng MC, Feng L, Peng J, Yuan JP, Wang JH. An effective method for the detoxification of cyanide-rich wastewater by Bacillus sp CN-22. Appl. Microbiol. Biotechnol. 98:3801-3807 (2014)

3. Luque-Almagro VM, Blasco R, Martinez-Luque M, Moreno-Vivan C, Castillo F, Roldan MD. Bacterial cyanide degradation is under review. Pseudomonas pseudoalcaligenes CECT5344, a case of an alkaliphilic cyanotroph. Biochem Sos Trans, 39:269-274 (2011)
4. Nsimba EB. Cyanide and Cyanide Complexes in the Gold-mine polluted land $i$ the East and Central Rand Goldfields South Africa Johannesburg. P.195 (2009)

5. Akinpelu EA, Amodu OS, Mpongwana N, Ntwampe SKO, Ojumu TV. Utilization of Beta vulgaris Agrowaste in Biodegradation of Cyanide Contaminated Wastewater Biotechnol, 59-75 (2015)

6. Huertas MJ, Sáez LP, Roldán MD, Luque-Almagro VM, Martínez-Luque M, Blasco R, Castillo F, Moreno-Vivián C, García-García I. An Alkaline cyanide degradation by Pseudomonas pseudoalcaligenes CECT5344 in a batch reactor Influence of $\mathrm{pH}$. J. Hazard. Mater. 179:72-78 (2010)

7. Mekuto L, Jackson VA, Ntwampe KS, Obed. Biodegradation of Free Cyanide Using Bacillus Sp Consortium Dominated by Bacillus Safensis Lichenformis and Tequilensis Strains: A Bioprocess Supported Solely with Whey. Bioremediat. Biodegrad. Pp. 1-7 (2013)

8. Ibrahim KK, Syed MA, Shukor MY. Biological remediation of cyanide: a review. Biotropia. Bogor, 22:151-163 (2015)

9. Dash, R.R., Gaur, A., Balomajumder, C. Cyanide in industrial wastewater and its removal: a review on biotreatment. J. Hazard. Mater. 163, 1e11 (2009)

10. Maniyam, M.N., F. Sjahrir, and A.L. Ibrahim. Bioremediation of Cyanide by Optimized resting Cells of Rhodococcus strains Isolated from Peninsular Malaysia. International Journal of Bioscience, Biochemistry and Bioinformatics, Vol. 1(2) : 98-101 (2011)

11. Perumal, M., J. Prabakaran., M. Kamaraj. Isolation and Characterization of Potential Cyanide Degrading Bacillus nealsonii from Different Industrial Effluents. International Journal of Chem. Tech. Research, Vol. 5(5) : 2357-2364 (2013)

12. Yamasaki M, Matsushita $Y$, Nyunoya H, Katayama Y, Namura M. Genetic and Immunochemical Characterization of Thiocyanate-Degrading Bacteria in Lake Water. Appl. Environ. Microbiol. 68:942-946 (2002)

13. Kumar, R. Remediation of Cyanide-Contaminated Environments Through Microbes and Plants (2016)

14. Fraga, E, G. Antimicrobial Susceptibility od Brazilian Clostridium difficile Strains Determined by Agar Dilution and Disk Diffusion. The Brazilian Journal of Infectious Diseases. 20(5):476-481 (2016)

15. Mirizadeh S, Yaghmaei S, Ghobadi Nejad Z. Biodegradation of cyanide by a new isolated strain under alkaline conditions and optimization by response surface methodology (RSM). J. Environ. Heal. Sci. Eng. 12(1):85 (2014) 